\title{
HUBUNGAN ANTARA ASUPAN KAFEIN, KUALITAS TIDUR DAN STATUS GIZI DENGAN TEKANAN DARAH
}

\author{
Sarah Khoerunisa ${ }^{1}$, Restu Amalia Hermanto ${ }^{2 *}$, Aminarista ${ }^{3}$ \\ 1,2,3Sekolah Tinggi Ilmu Kesehatan Holistik \\ *Korespondensi: Jl. Veteran No. 272 Ciseureuh Purwakarta, Email: ailama.restu@gmail.com
}

\begin{abstract}
ABSTRAK
Latar Belakang: Pada negara berkembang kategori usia 20-24 tahun banyak mengalami tekanan darah tinggi, 9,4\% laki-laki dan 8,9\% perempuan. Di Indonesia kejadian tekanan darah tinggi $\geq 18$ tahun adalah $25,8 \%$. Tekanan darah pada mahasiswa dapat dipengaruhi oleh asupan kafein, kualitas tidur dan status gizi.

Tujuan: Penelitian ini bertujuan untuk mengetahui hubungan antara asupan kafein, kualitas tidur dan status gizi dengan tekanan darah.

Metode: Penelitian ini dilakukan pada mahasiswa STT Wastukancana dengan desain penelitian cross sectional, melibatkan 82 subjek penelitian yang dipilih secara simple random sampling. Asupan kafein diukur menggunakan food frequency Questionnaire (FFQ) semi kuantitatif, kualitas tidur diukur menggunakan kuesioner Pittsburgh Sleep Quality Index (PSQI), status gizi diukur menggunakan Indeks Massa Tubuh (IMT), dan tekanan darah diukur menggunakan alat sphygnomanometer digital. Hubungan masing-masing variabel bebas dengan tekanan darah sistolik diuji menggunakan pearson product momment. Sedangkan hubungan variabel bebas dengan tekanan darah diastolik diuji menggunakan rank spearman. Uji multivariat menggunakan uji regresi linear ganda.

Hasil: Sebagian besar subjek memiliki tekanan darah sistolik tinggi (61\%) dan tekanan darah diastolik tinggi $(74,4 \%)$. Asupan kafein, kualitas tidur dan status gizi masing-masing memiliki hubungan dengan tekanan darah sistolik dan tekanan darah diastolik. Faktor-faktor yang berpengaruh meningkatkan tekanan darah sistolik adalah asupan kafein $(B=0,12 ; p=0,004)$, kualitas tidur $(B=1,36 ; p=0,001)$ dan status gizi $(B=1,25 ; p=0,001)$. Buruknya kualitas tidur subjek pada penelitian ini dapat disebabkan oleh adanya gangguan-gangguan baik saat sebelum tertidur ataupun pada saat tidur.
\end{abstract}

Simpulan: Tekanan darah tinggi dipengaruhi oleh asupan kafein, kualitas tidur dan status gizi. Kata kunci: Asupan kafein, Kualitas tidur, Status Gizi, Tekanan darah

\begin{abstract}
Background: approximately 9.4\% of men and 8.9\% of women in developing countries aged 20-24 years experience high blood pressure. In Indonesia the incidence of high blood pressure in the age group over 18 years is $25.8 \%$. Blood pressure in students can be influenced by caffeine intake, sleep quality and nutritional status.

Objective: This study aims to determine the relationship between caffeine intake, sleep quality and nutritional status with blood pressure.

Method: This research was conducted at STT Wastukancana students using cross sectional research design and 82 subjects were selected by simple random sampling. Caffeine intake was measured using a semi-quantitative food frequency Questionnaire (SQ-FFQ), sleep quality was measured using the Pittsburgh Sleep Quality Index (PSQI) questionnaire, nutritional status was measured using Body Mass Index (BMI), blood pressure was measured using a digital sphygnomanometer. The relationship of each independent variable with systolic blood pressure was tested using Pearson product momment, whereas the relationship between the independent variable and diastolic blood pressure was tested using the Spearman rank. Multivariate test used multiple linear regression test.
\end{abstract}

Results: Most subjects had high systolic blood pressure (61\%) and high diastolic blood pressure (74.4\%). Caffeine intake, sleep quality and nutritional status each have a relationship with systolic blood pressure and diastolic blood pressure. Factors associated with increased systolic blood 
pressure were caffeine intake ( $B=0.12 ; p=0.004)$, sleep quality $(B=1.36 ; p=0.001)$ and nutritional status $(B=1.25 ; p=0.001)$. Poor sleep quality of the subjects in this study can be caused by disturbances both before falling asleep or during sleep.

Conclusion: High blood pressure is influenced by caffeine intake, sleep quality and nutritional status.

Key words: Caffeine intake, Sleep quality, Nutritional status, Blood Pressure

\section{PENDAHULUAN}

World Health Organization (WHO)

melaporkan bahwa kejadian tekanan darah tinggi di negara-negara berkembang banyak terjadi pada kelompok usia 20-24 tahun, yaitu $9,4 \%$ pada laki-laki dan $8,9 \%$ pada perempuan $^{1}$. Di Indonesia $25,8 \%$ penduduk Indonesia mengalami kejadian tekanan darah pada usia lebih dari sama dengan 18 tahun ${ }^{2}$. Berdasarkan data Dinas Kesehatan Kabupaten Purwakarta, prevalensi tekanan darah tinggi pada kelompok penduduk usia 20-44 tahun yaitu sebanyak $14 \%$ pada lakilaki dan 20,4\% pada perempuan. Tekanan darah dapat dipengaruhi oleh beberapa faktor, seperti asupan kafein, kualitas tidur dan status gizi. ${ }^{3-5}$

Kafein merupakan senyawa kimiawi yang ada pada beberapa minuman seperti, kopi, teh, minuman berenergi, minuman berkarbonasi dan minuman coklat $^{6}$. Berdasarkan penelitian terdahulu, sekitar $80 \%$ penduduk dunia mengonsumsi kafein setiap harinya. ${ }^{7}$ Asupan kafein pada mahasiswa dipengaruhi oleh faktor suka sekitar 80,83\%. ${ }^{8}$ Kualitas tidur juga menjadi faktor yang mempengaruhi tekanan darah. Menurut penelitian sebelumnya diketahui bahwa ada hubungan yang signifikan antara kualitas tidur dengan tekanan darah. ${ }^{4}$ Kualitas tidur mahasiswa dipengaruhi oleh beberapa faktor seperti, usia, depresi, media elektronik dan aktivitas pagi. 9,10

Selain asupan kafein dan kualitas tidur, status gizi juga memengaruhi tekanan darah. Status gizi pada mahasiswa dapat meningkat dengan dipengaruhi oleh, faktor sosial dan faktor media. ${ }^{11}$ Status gizi yang meningkat akan menyebabkan terjadinya penumpukan jaringan lemak sehingga akan meningkatkan resistensi pembuluh darah, hal ini dapat membuat tekanan darah meningkat. 4

Berdasarkan latar belakang yang telah diuraikan, peneliti tertarik untuk meneliti hubungan antara asupan kafein, kualitas tidur dan status gizi dengan tekanan darah khususnya pada mahasiswa. Subjek pada penelitian ini adalah mahasiswa Sekolah Tinggi Teknologi (STT) Wastukancana dengan rentang usia 20-24 tahun. Berdasarkan studi pendahuluan mahasiswa jurusan teknik adalah mahasiswa yang memiliki aktivitas perkuliahan yang padat dibandingkan dengan jurusan lain. ${ }^{12}$ Rentang usia 20-24 tahun adalah rentang usia dengan tekanan darah tertinggi. ${ }^{1}$ Mahasiswa teknik adalah mahasiswa yang memiliki aktivitas perkuliahan yang padat dibandingkan dengan jurusan lain, sehingga peneliti tertarik untuk melakukan penelitian mengenai hubungan antara asupan kafein, kualitas tidur dan status gizi dengan tekanan darah pada mahasiswa.

\section{METODE PENELITIAN}

Penelitian ini dilaksanakan di Sekolah Tinggi Teknologi Wastukancana Purwakarta pada bulan Mei 2018. Penelitian ini merupakan penelitian kuantitatif dengan metode observasi dan desain penelitian cross sectional. Subjek pada penelitian ini adalah mahasiswa jurusan Teknik Informatika dan Teknik Mesin berusia 20-24 tahun sebanyak 119 subjek. Pada saat penelitian terjadi drop out sebanyak 37 subjek sehingga total subjek penelitian 82 subjek. Subjek dipilih menggunakan metode simple random sampling. Data identitas subjek diambil dengan menggunakan kuesioner yang diisi langsung oleh masing-masing subjek. Asupan kafein diukur dengan menggunakan Food Frequency Questionnaire (FFQ) semi kuantitatif dalam satuan miligram (mg). Asupan kafein dikategorikan menjadi rendah (jika asupan $<50 \mathrm{mg} /$ hari), sedang (jika asupan $50-300 \mathrm{mg} /$ hari) dan tinggi (jika asupan $>300 \mathrm{mg} /$ hari). Kualitas tidur 
diukur dengan menggunakan kuesioner Pittsburgh Sleep Quality Index (PSQI) yang langsung diisi oleh masing-masing subjek. Kualitas tidur dikategorikan menjadi kualitas tidur baik apabila skor PSQI $\leq 5$ dan buruk jika skor $>5$. Status gizi subjek diukur menggunakan Indeks Massa Tubuh (IMT), yaitu perhitungan dengan menggunakan parameter berat badan dan tinggi badan. Status gizi dikategorikan menjadi gizi kurang $\left(<18,5 \mathrm{~kg} / \mathrm{m}^{2}\right)$, normal $(18,5-24,9$ $\left.\mathrm{kg} / \mathrm{m}^{2}\right)$, gemuk $\left(25-29,9 \mathrm{~kg} / \mathrm{m}^{2}\right)$, obesitas 1 (30-34,9 kg/m²). Tekanan darah diukur dengan menggunakan sphygnomanometer digital yang diukur langsung oleh petugas kesehatan yang diulang sebanyak 3 kali berturut-turut.
Pengolahan dan analisis data untuk melihat hubungan antara masing-masing variabel bebas, yaitu asupan kafein, kualitas tidur dan status gizi dengan tekanan darah sistolik menggunakan uji pearson product moment. Hubungan antara masing-masing variabel bebas, yaitu asupan kafein, kualitas tidur dan status gizi dengan tekanan darah diastolik menggunakan uji rank spearman. Hubungan antara asupan kafein, kualitas tidur dan status gizi secara bersamaan dengan tekanan darah sistolik menggunakan uji regresi linear ganda.

\section{HASIL PENELITIAN}

Tabel 1. Distribusi frekuensi subjek penelitian

\begin{tabular}{|c|c|c|}
\hline Variabel & $\mathbf{n}$ & $\%$ \\
\hline \multicolumn{3}{|l|}{ Jenis kelamin } \\
\hline Laki-laki & 57 & 69,5 \\
\hline Perempuan & 25 & 30,5 \\
\hline \multicolumn{3}{|l|}{ Riwayat keluarga hipertensi } \\
\hline Ya & 36 & 43,9 \\
\hline Tidak & 46 & 56,1 \\
\hline \multicolumn{3}{|l|}{ Merokok } \\
\hline Tidak merokok & 39 & 47,6 \\
\hline Perokok ringan (1-10 batang) & 36 & 43,9 \\
\hline Perokok sedang (11-20 batang) & 7 & 8,5 \\
\hline \multicolumn{3}{|l|}{ Tekanan darah sistolik } \\
\hline Hipotensi $(\leq 60 \mathrm{mmHg}$ ) & 0 & 0 \\
\hline Normal (91-120 mmHg) & 32 & 39 \\
\hline Pre-Hipertensi (121-140 mmHg) & 36 & 43,9 \\
\hline Hipertensi (>140 mmHg) & 14 & 17,1 \\
\hline \multicolumn{3}{|l|}{ Tekanan darah diastolik } \\
\hline Hipotensi $(\leq 60 \mathrm{mmHg}$ ) & 1 & 1,2 \\
\hline Normal (61-80 mmHg) & 20 & 24,4 \\
\hline Pre-Hipertensi (81-90 mmHg) & 55 & 67,1 \\
\hline Hipertensi (>90 mmHg) & 6 & 7,3 \\
\hline \multicolumn{3}{|l|}{ Asupan kafein } \\
\hline Cukup (<300 mg) & 82 & 100 \\
\hline Tinggi ( $\geq 300 \mathrm{mg}$ ) & 0 & 0 \\
\hline \multicolumn{3}{|l|}{ Kualitas tidur } \\
\hline Baik $(\leq 5)$ & 16 & 19,5 \\
\hline Buruk (5) & 66 & 80,5 \\
\hline \multicolumn{3}{|l|}{ Status Gizi } \\
\hline Gizi kurang $\left(<18,5 \mathrm{~kg} / \mathrm{m}^{2}\right)$ & 8 & 9,8 \\
\hline Normal $\left(18,5-24,9 \mathrm{~kg} / \mathrm{m}^{2}\right)$ & 48 & 58,5 \\
\hline Pre-obesitas $\left(25-29,9 \mathrm{~kg} / \mathrm{m}^{2}\right)$ & 23 & 28 \\
\hline Obesitas I ( $\left.30-34,9 \mathrm{~kg} / \mathrm{m}^{2}\right)$ & 3 & 3,7 \\
\hline
\end{tabular}

Berdasarkan hasil distribusi frekuensi yang disajikan pada Tabel 1, laki-laki lebih dominan pada penelitian ini $(69,5 \%)$ dibandingkan dengan perempuan $(30,5 \%)$.
Sebanyak 46 subjek $(56,1 \%)$ tidak memiliki riwayat tekanan darah tinggi dan 43 subjek $(52,4 \%)$ termasuk ke dalam kategori perokok yang kemudian dibagi menjadi 2 
kategori, yaitu perokok sedang $(43,9 \%)$ dan perokok berat $(8,5 \%)$. Pada penelitian ini, 36 subjek memiliki tekanan darah sistolik pre-hipertensi. Sebanyak 55 subjek juga termasuk pada kategori tekanan darah diastolik pre-hipertensi. Berdasarkan hasil kuesioner PSQI diketahui bahwa 66 subjek
$(80,5 \%)$ memiliki kualitas tidur yang buruk. Sebanyak 48 subjek (58,5\%) memiliki status gizi normal dan 23 subjek (28\%) memiliki status gizi pre-obesitas. Pada penelitian ini usia subjek rata-rata adalah 20,68 dengan minimal usia 20 tahun dan maksimal 24 tahun.

Tabel 2 Hasil Uji Hubungan antara Masing-Masing Variabel Bebas dengan Variabel Terikat

\begin{tabular}{|c|c|c|c|}
\hline Variabel & Mean \pm SD & $p$ & $\boldsymbol{r}$ \\
\hline Asupan kafein & $196,33 \pm 29,78$ & \multirow{2}{*}{$0,001^{\mathrm{a}}$} & \multirow{2}{*}{0,39} \\
\hline Tekanan darah sistolik & $126,63 \pm 12,78$ & & \\
\hline Asupan kafein & $196,33 \pm 29,78$ & \multirow{2}{*}{$0,001^{b}$} & \multirow{2}{*}{0,373} \\
\hline Tekanan darah diastolik & $82,29 \pm 7,4$ & & \\
\hline Kualitas tidur & $8,79 \pm 3,25$ & \multirow{2}{*}{$0,001^{a}$} & \multirow{2}{*}{0,439} \\
\hline Tekanan darah sistolik & $126,63 \pm 12,78$ & & \\
\hline Kualitas tidur & $8,79 \pm 3,25$ & \multirow{2}{*}{$0,023^{b}$} & \multirow{2}{*}{0,252} \\
\hline Tekanan darah diastolik & $82,29 \pm 7,4$ & & \\
\hline Status Gizi & $23,79 \pm 3,44$ & \multirow{2}{*}{$0,001^{\mathrm{a}}$} & \multirow{2}{*}{0,415} \\
\hline Tekanan darah sistolik & $126,63 \pm 12,78$ & & \\
\hline Status Gizi & $23,79 \pm 3,44$ & \multirow{2}{*}{$0,008^{b}$} & \multirow{2}{*}{0,292} \\
\hline Tekanan darah diastolik & $82,29 \pm 7,4$ & & \\
\hline
\end{tabular}

a Uji Pearson Product Moment

b Uji Rank Spearman

Berdasarkan hasil uji korelasi yang disajikan pada Tabel 2, diketahui bahwa ada hubungan antara asupan kafein dengan tekanan darah sistolik dengan nilai $p 0,001$ dengan kekuatan hubungan sangat lemah dibuktikan dengan nilai $r$ 0,39. Ada hubungan juga antara asupan kafein dengan tekanan darah diastolik $(p=0,001)$ dan hubungan kekuatan sangat lemah $(r=0,373)$. Terdapat juga hubungan antara kualitas tidur dengan tekanan darah sistolik responden dengan nilai $p$ 0,001 $(p<0,05)$ dan kekuatan hubungan sangat lemah dengan nilai $r$ 0,439. Kualitas tidur juga memiliki hubungan dengan tekanan darah diastolik dengan nilai $p 0,023(p<0,05)$ dan kekuatan korelasi sangat lemah dengan nilai $r$ 0,252. Status gizi juga memiliki hubungan dengan tekanan darah sistolik dengan nilai $p 0,001(p<0,05)$ dan kekuatan hubungan sangat lemah, yaitu nilai $r$ $(0,415)$. Selain berhubungan dengan tekanan darah sistolik, status gizi juga berhubungan dengan tekanan darah diastolik dengan nilai $p 0,008(p<0,05)$ dan kekuatan hubungan sangat lemah, ditunjukkan dengan nilai $r$ 0,292.
Berdasarkan hasil analisis multivariat yang disajikan pada Tabel 3, didapat persamaan sebagai berikut:

Sistolik $=0,12$ Asupan kafein $+1,36$ Kualitas tidur $+1,25$ Status Gizi $+62,2$

Variabel asupan kafein memiliki nilai positif, artinya jika asupan kafein subjek meningkat maka tekanan darah sistolik juga akan mengalami peningkatan. Kenaikan 1 mg asupan kafein responden maka akan meningkatkan $0,12 \mathrm{mmHg}$. Nilai $p$ pada variabel asupan kafein adalah 0,004 $(p<0,05)$, nilai ini menunjukkan variabel asupan kafein berpengaruh terhadap tekanan darah sistolik.

Variabel kualitas tidur memiliki nilai positif yang menunjukkan hubungan yang searah, artinya jika adanya peningkatan pada variabel kualitas tidur maka tekanan darah sistolik juga akan mengalami peningkatan. Kenaikan 1 poin pada skor kualitas tidur maka akan meningkatkan 1,36 mmHg tekanan darah sistolik. Nilai $p$ pada kualitas tidur adalah 0,001 $(p<0,05)$, artinya kualitas tidur berpengaruh nyata terhadap variabel tekanan darah sistolik. 
Tabel 3 Hubungan antara asupan kafein, kualitas tidur dan Indeks Massa Tubuh dengan tekanan darah

\begin{tabular}{clccc}
\hline & Faktor risiko & B & Nilai $\boldsymbol{t}$ & Signifikansi nilai $\boldsymbol{p}$ \\
\hline \multirow{4}{*}{ Sistolik } & Constant & 62,2 & 6,14 & 0,001 \\
\cline { 2 - 5 } & Asupan Kafein & 0,12 & 2,97 & 0,004 \\
\cline { 2 - 5 } & Kualitas tidur & 1,36 & 3,82 & 0,001 \\
\cline { 2 - 5 } & Status Gizi & 1,25 & 2,79 & 0,001 \\
\hline \multicolumn{2}{c}{ Adjusted R $\mathbf{R}^{2}$} & & & 0,373 \\
\hline
\end{tabular}

Variabel status gizi memiliki nilai positif, artinya adanya hubungan searah antara status gizi dengan tekanan darah sistolik, yaitu jika status gizi mengalami kenaikan maka tekanan darah sistolik akan mengalami kenaikan. Bila terjadi kenaikan 1 $\mathrm{kg} / \mathrm{m}^{2}$ pada status gizi maka tekanan darah sistolik juga akan mengalami kenaikan sebesar $1,25 \mathrm{mmHg}$. Nilai $p$ pada status gizi menunjukkan nilai $0,001(p<0,05)$, artinya adanya pengaruh antara status gizi terhadap tekanan darah sistolik.

Nilai konstanta pada penelitian ini memiliki nilai yang cukup besar, yaitu 62,2, hal ini disebabkan oleh kekuatan hubungan antara variabel-variabel bebas yang diteliti dengan variabel terikat adalah sangat lemah $(r>0,25-0,5)$ dan juga disebabkan oleh adanya faktor-faktor lain yang mempengaruhi kenaikan tekanan darah sistolik. Nilai Adjusted $R^{2}$ adalah 0,373 atau $37,3 \%$ tekanan darah sistolik dapat dijelaskan oleh asupan kafein, kualitas tidur dan status gizi secara bersama-sama. Nilai $F$ hitung pada penelitian ini lebih besar dibandingkan dengan nilai $F$ tabel, yaitu 17,09 sehingga dapat disimpulkan bahwa asupan kafein, kualitas tidur dan status gizi secara bersama-sama berpengaruh terhadap tekanan darah sistolik.

\section{PEMBAHASAN}

Pada penelitian ini menunjukkan adanya hubungan antara asupan kafein dengan tekanan darah sistolik dan diastolik, dengan nilai $p=0,001$. Seluruh subjek pada penelitian ini memiliki asupan kafein dalam kategori dengan rata-rata asupan 196,33 $\mathrm{mg} /$ hari. Menurut hasil meta analisis, bahwa asupan kafein memiliki hubungan yang terbalik dengan tekanan darah menurut dosis yang diberikan. ${ }^{13}$ Sehingga dapat disimpulkan bahwa bila asupan kafein sangat rendah atau sangat tinggi ( $\geq 300 \mathrm{mg} /$ hari) dapat menurunkan risiko hipertensi secara signifikan dibandingkan dengan mereka yang mengonsumsi kafein secara cukup $(<300 \mathrm{mg} / \mathrm{hari}) .^{14}$ Hal ini disebabkan karena asupan kafein yang berasal dari minuman seperti kopi dan lainlain kaya akan sumber kalium dan polifenol. Kalium diketahui dapat meningkatkan relaksasi otot polos pembuluh darah dan dapat memberi efek untuk menurunkan tekanan darah baik tekanan darah sistolik maupun tekanan darah diastolik. ${ }^{15}$ Polifenol utama yang terkandung pada kopi adalah asam klorogenat yang dapat menurunkan tekanan darah dan meningkatkan bioavailibilitas oksida nitrit. ${ }^{16}$ Hasil metaanalisis memberikan hasil perbandingan perubahan tekanan darah sistolik dan tekanan darah diastolik pada subjek yang diberikan tablet kafein dan kafein yang berasal dari minuman. Penelitian ini menunjukkan bahwa adanya peningkatan tekanan darah pada subjek yang diberi tablet kafein dibandingkan dengan kafein dari minuman. ${ }^{17}$

Penelitian ini sejalan dengan penelitian case control yang dilakukan dengan membagi dua kelompok kasus dan kontrol dengan jumlah subjek sama. Kelompok kasus adalah subjek dengan tekanan darah tinggi dan kelompok kontrol adalah subjek dengan tekanan darah normal. Frekuensi asupan kafein 0 cangkir per hari lebih banyak pada kelompok kontrol (80,9\%) dibandingkan dengan kelompok kasus $(63,8 \%)$, sementara frekuensi asupan kafein dengan porsi cukup lebih banyak pada kelompok kasus $(27,7 \%)$ dibandingkan dengan kelompok kontrol $(8,5 \%) .{ }^{18}$

Penelitian lain yang sejalan dengan penelitian ini adalah penelitian yang 
dilakukan di Amerika Serikat dengan ratarata subjek orang Asia dan desain penelitian cross sectional, subjek di ukur tekanan darahnya setelah mengonsumsi kafein. Penelitian ini menunjukkan bahwa pada 1 jam pertama setelah mengonsumsi kafein adanya peningkatan secara signifikan pada tekanan darah sistolik dan tekanan darah diastolik. Berdasarkan hasil tersebut maka pada penelitian ini ditemukan adanya hubungan antara asupan kafein dengan tekanan darah $(p<0,05) .{ }^{19}$ Sebagian besar mahasiswa dapat mengonsumsi kafein setiap harinya, karena dipengaruhi oleh beberapa faktor di antaranya seperti, faktor suka sebanyak $53,67 \%$ dan faktor lingkungan dan sosial sebanyak 17,65\%. ${ }^{8}$ Asupan kafein yang dikonsumsi secara terus menerus dapat meningkatkan reseptor adenosin. Adenosin di ginjal akan mengurangi filtrasi glomerulus dan aliran darah renal yang selanjutnya meningkatkan tekanan darah. ${ }^{20}$

Hasil pada penelitian ini menunjukkan adanya hubungan antara kualitas tidur baik dengan tekanan darah sistolik maupun dengan tekanan darah diastolik dengan nilai $p$ masing-masing, 0,001 dan 0,023 . Kekuatan korelasi antara kualitas tidur dengan tekanan darah sistolik dan diastolik masing-masing adalah 0,439 dan 0,252 yang artinya memiliki korelasi sangat lemah. Hal ini dibuktikan dengan total persentase subjek yang memiliki tekanan darah sistolik pre-hipertensi $(43,9 \%)$ dan hipertensi $(17,1 \%)$ lebih besar dibandingkan dengan normal (39\%) dan hipotensi (0\%) dan kualitas tidur buruk $(80,5 \%)$ yang juga lebih banyak dibandingkan dengan kualitas tidur baik $(19,5 \%)$.

Hasil penelitian ini diperkuat oleh penelitian yang dilakukan di China, penelitian ini menunjukkan bahwa subjek dengan tekanan darah tinggi lebih banyak terjadi pada kelompok subjek dengan kualitas tidur yang buruk $(69,74 \%)$ dibandingkan subjek dengan kualitas tidur baik dengan rata-rata tekanan darah sistolik seluruh subjek $136 \mathrm{mmHg}$ dan tekanan darah diastolik $86 \mathrm{mmHg} .{ }^{21}$ Penelitian lain yang mendukung adanya hubungan antara kualitas tidur dengan tekanan darah adalah penelitian dengan desain cross sectional pada 71 subjek, menunjukkan hasil bahwa subjek dengan kualitas tidur buruk memiliki tekanan darah sistolik tinggi $(39,4 \%)$ lebih besar dibandingkan dengan tekanan darah sistolik normal, begitu juga dengan subjek yang memiliki kualitas tidur buruk memiliki tekanan darah diastolik tinggi $(53,5 \%)$ lebih besar dibandingkan dengan tekanan darah diastolik normal. ${ }^{22}$

Penelitian ini dilaksanakan beberapa hari setelah proses Ujian Tengah Semester (UTS), hal ini mempengaruhi buruknya kualitas tidur subjek. Menurut penelitian yang dilakukan di Jerman, sebanyak 53,3\% subjek memiliki kualitas tidur yang buruk ketika periode ujian sedang berlangsung dibandingkan pada satu bulan sebelum atau sesudah ujian dilaksanakan. $^{23}$ Penelitian lain juga menyebutkan bahwa penggunaan smartphone secara terus menerus dapat mempengaruhi kualitas tidur, hal ini dibuktikan pada penelitian yang dilakukan di Turki, bahwa subjek dengan kualitas tidur yang buruk banyak ditemukan pada subjek dengan penggunaan smartphone yang tinggi $(45,7 \%)$ dibandingkan subjek dengan penggunaan smartphone rendah atau tidak menggunakan smartphone. ${ }^{24} \mathrm{Di}$ Indonesia, sekitar $36 \%$ mahasiswa menggunakan smartphone sepanjang hari atau hampir 24 jam. ${ }^{25}$

Status Gizi merupakan salah satu variabel yang mempengaruhi tekanan darah, baik sistolik maupun diastolik. Pada penelitian ini menunjukkan bahwa tekanan darah sistolik baik pre-hipertensi $(43,9 \%)$ maupun hipertensi (17,1\%) lebih besar dibandingkan dengan normal (39\%) dan hipotensi $(0 \%)$ dan Indeks Massa Tubuh pre-obesitas dan obesitas sekitar 31,7\%. Begitu juga dengan tekanan darah diastolik subjek. Penelitian ini menghasilkan analisis bivariat yang menyatakan bahwa adanya hubungan antara Indeks Massa Tubuh dengan tekanan darah sistolik dan tekanan darah diastolik secara signifikan dengan nilai $p<0,05$.

Penelitian ini sejalan dengan penelitian cross sectional di Thailand, yaitu 
prevalensi pre-hipertensi $(13,1 \%)$ dan hipertensi $(13,8 \%)$ pada subjek yang memiliki Indeks Massa Tubuh dengan kategori obesitas dan rata-rata Indeks Massa tubuh $25,21 \mathrm{~kg} / \mathrm{m}^{2}$ pada kelompok hipertensi.26 Penelitian lain yang juga sejalan dengan penelitian ini adalah penelitian yang dilakukan di Yunani dengan desain cohort pada rentang usia 19-30 tahun. Penelitian tersebut melaporkan bahwa prevalensi tekanan darah tinggi paling tinggi pada kategori Indeks Massa Tubuh obesitas $(64,1 \%)$ dan overweight $(32,5 \%)$ dibandingkan dengan Indeks Massa Tubuh normal. ${ }^{27}$

Menurut Papathansiou et al, Indeks Massa Tubuh adalah faktor yang langsung berhubungan dengan tekanan darah baik sistolik maupun diastolik. Setiap kenaikan 1 angka Indeks Massa Tubuh sangat berhubungan dengan rata-rata kenaikan 2 mmHg tekanan darah sistolik dan juga kenaikan 1,3 mmHg tekanan darah diastolik. ${ }^{27}$ Hubungan Indeks Massa Tubuh dengan tekanan darah dapat terjadi karena meningkatnya retensi natrium oleh ginjal. ${ }^{28}$ Variabel-variabel yang dapat dilakukan analisis multivariat adalah asupan kafein, kualitas tidur, status gizi dan tekanan darah sistolik, karena empat variabel ini yang memenuhi syarat untuk melakukan analisis multivariat. ${ }^{29}$ Berdasarkan hasil uji multivariat pada Tabel 3., variabel asupan kafein, kualitas tidur dan status gizi secara bersama-sama dapat berpengaruh sebesar 37,3\% terhadap tekanan darah sistolik, sedangkan sisanya $62,7 \%$ tekanan darah sistolik dipengaruhi oleh faktor-faktor lain seperti stres, jenis kelamin, aktivitas fisik dan faktor lain yang tidak menjadi fokus pada penelitian ini.

Pada penelitian ini, pengaruh variabel bebas terhadap variabel terikat yaitu antara asupan kafein, kualitas tidur dan status gizi menunjukkan hasil hubungan positif dan pengaruh yang signifikan terhadap tekanan darah sistolik. Dari ketiga variabel bebas, kualitas tidur memiliki nilai Beta tertinggi, yaitu 1,36. Hal ini terjadi karena tidur adalah kebutuhan seluruh manusia. Pada penelitian ini ratarata durasi tidur malam subjek penelitian adalah lumayan buruk, yaitu 5-6 jam. Hal ini tidak sesuai dengan waktu tidur malam yang dianjurkan oleh National Sleep Foundation, kebutuhan tidur malam yang baik berdasarkan usia pada kategori 18-25 tahun adalah 7-9 jam/hari. ${ }^{30}$

Rata-rata efisiensi tidur subjek lumayan tidak efisien sehingga dapat memperburuk kualitas tidur subjek dan rata-rata daytime dysfunction subjek yang lumayan sering terjadi dalam sepekan, walaupun rata-rata subjek merasakan kualitas tidur yang lumayan baik. Kejadian ini dapat dipengaruhi oleh subjek yang sudah terbiasa dengan durasi tidur tersebut walaupun rata-rata durasi tidur tidak sesuai dengan kebutuhan tidur yang dianjurkan. Hal ini diperkuat dengan tidak adanya subjek yang mengonsumsi obat tidur walaupun durasi tidur tidak tercukupi dengan durasi yang dibutuhkan. Tekanan darah juga dapat dipengaruhi akibat kenaikan status gizi, hal ini sangat dipengaruhi oleh lingkungan dalam pemilihan makanan dan kebiasaan makan. ${ }^{31}$

Asupan kafein dapat dikatakan sebagai faktor yang juga mempengaruhi kenaikan tekanan darah sistolik. Pada penelitian yang dilakukan di Amerika Serikat pada 37.602 subjek, rata-rata asupan kafein adalah cukup, yaitu 165 mg/hari. ${ }^{32}$ Asupan kafein pada mahasiswa dipengaruhi oleh ujian atau tugas. Menurut penelitian yang dilakukan pada mahasiswa kesehatan di Pakistan pada tahun 2016, sekitar 92,8\% subjek mengonsumsi kafein untuk tetap terjaga pada masa ujian sedang berlangsung. ${ }^{33}$

\section{SIMPULAN}

Tekanan darah tinggi dapat dipengaruhi oleh faktor-faktor seperti, asupan kafein, kualitas tidur dan status gizi. Hubungan yang paling erat antara asupan kafein, kualitas tidur dan status gizi dengan tekanan darah adalah kualitas tidur.

Berdasarkan hasil dari penelitian ini, diketahui bahwa tekanan darah tinggi banyak terjadi pada kelompok usia 20-24 tahun. Disarankan untuk mulai mengatur pola hidup sehat dan baik khususnya 
dengan mengatur asupan kafein, kualitas tidur dan pola makan yang baik dan sesuai dengan kebutuhan. Cara yang dapat ditempuh adalah dengan melakukan sosialisasi pada mahasiswa melalui Institusi dan organisasi terkait.

\section{DAFTAR PUSTAKA}

1. WHO. A global brief on hypertension: silent killer, global public health crisis. Switzerland: World Health Organization, 2013. 12.

2. Kemenkes RI. Riset kesehatan dasar 2013. Jakarta: Badan Penelitian dan Pengembangan Kesehatan Kementerian Kesehatan RI. 2013.

3. Devi AVS. hubungan asupan kafein dengan tekanan darah pada pekerja bagian produksi PT. Tiga Serangkai Surakarta. Naskah Publikasi. Program Studi Ilmu Gizi Fakultas Kesehatan Universitas Muhammadiyah Surakarta. 2016.

4. Lumantow I, Rompas S, Onibala F. Hubungan kualitas tidur dengan tekanan darah pada remaja di desa Tombasian Atas kecamatan Kawangkoan Barat. J Keperawatan. 2016;4(1).

5. Sumayku IM, Pandelaki K, Wongkar MCP. Hubungan indeks massa tubuh dan lingkar pinggang dengan tekanan darah pada mahasiswa fakultas kedokteran Universitas Sam Ratulangi. J e-Clinic. 2014;2(2).

6. Rachmawati DA. Pengaruh pemberian minuman kopi robusta, susu, dan campuran keduanya terhadap kualitas tidur mahasiswa semester VII Universitas Muhammadiyah Purwokerto. Skripsi. Program Studi Farmasi Fakultas Farmasi Universitas Muhammadiyah Purwokerto. 2017.

7. Sadock B, Sadock V, Ruiz P. Kaplan \& Sadock's synopsis of psychiatry. Philadelphia: Lippincott Williams \& Wilkins. 2015.

8. Purdiani M. Hubungan penggunaan minuman berkafein terhadap pola tidur dan pengaruhnya pada tingkah laku mahasiswa/i Universitas Surabaya.
Calypra: J Ilmiah Mahasiswa Univ Surabaya. 2014;3(1).

9. Mirbagher L, Gholamrezaei A, Hosseini $\mathrm{N}$, Sayed Bonakdar Z. Sleep quality in women with systemic lupus erythematosus: contributing factors and effects on health-related quality of life. Intl J Rheumatic Diseases. 2016 Mar;19(3):305-311.

10. Owens J, Adolescent Sleep Working Group. Insufficient sleep in adolescents and young adults: an update on causes and consequences. Pediatrics. 2014 Sep 1;134(3):921-32.

11. Evan E, Wiyono J, Candrawati E. Hubungan antara pola makan dengan kejadian obesitas pada mahasiswa di Universitas Tribhuwana Tunggadewi Malang. Nursing News: J Ilmiah Mahasiswa Keperawatan. 2017 Dec $5 ; 2(3)$.

12. Nurwidyastuti D. Hubungan konsumsi zat gizi, status gizi, dan faktor-faktor lain dengan status kebugaran mahasiswa departemen arsitektur fakultas teknik Universitas Indonesia tahun 2012. Skripsi Fakultas Kesehatan Masyarakat Program Studi Sarjana Gizi Universitas Indonesia. 2012.

13. Xie $\mathrm{C}$, et al. Coffee consumption and risk of hypertension: A systematic review and dose-response meta-analysis of cohort studies. J Human Hypertension. 2018 Feb;32(2):83-93.

14. Chei CL, Loh JK, Soh A, Yuan JM, Koh WP. Coffee, tea, caffeine, and risk of hypertension: the Singapore Chinese Health Study. European J Nutrition. 2018 Jun 1; 57(4). 1333-42.

15. Ekmekcioglu C, Elmadfa I, Meyer AL, Moeslinger $\mathrm{T}$. The role of dietary potassium in hypertension and diabetes. J Physiology Biochemistry. 2016 Maret 1;72(1):93-106.

16. Watanabe $\mathrm{T}$, et al. The blood pressurelowering effect and safety of chlorogenic acid from green coffee bean extract in essential hypertension. Clinical experimental hypertension. 2006 Jan 1;28(5):439-49.

17. Noordzij $M$, et al. Blood pressure response to chronic intake of coffee and 
caffeine: a meta-analysis of randomized controlled trials. J Hypertens. 2005;23:921-8.

18. Martiani A. Faktor risiko hipertensi ditinjau dari kebiasaan minum kopi. Skripsi. Program Studi Ilmu Gizi Fakultas Kedokteran Universitas Diponegoro. 2012.

19. Kurtz AM, Leong J, Anand M, Dargush AE, Shah SA. Effects of caffeinated versus decaffeinated energy shots on blood pressure and heart rate in healthy young volunteers. Pharmacotherapy: J Human Pharmacology Drug Therapy. 2013 Aug;33(8):779-86.

20. Guessous I, Eap CB, Bochud M. Blood pressure in relation to coffee and caffeine consumption. Current hypertension reports. 2014 Sep 1;16(9):468.

21. Liu RQ et al. Poor sleep quality associated with high risk of hypertension and elevated blood pressure in China: results from a large population-based study. Hypertension Research.2016 Jan;39(1):54.

22. Magfirah I. Hubungan Kualitas Tidur Dengan Tekanan Darah Pada
Mahasiswi Program Studi S1

Fisioterapi Angkatan 2013 Dan 2014 Di Universitas Hasanuddin. Skripsi. Program Studi Fisioterapi Fakultas Kedokteran Universitas Hasanuddin. 2016.

23. Zunhammer $M$, Eichhammer P, Busch V. Sleep quality during exam stress: The role of alcohol, caffeine and nicotine. PloS one. 2014 Oct 3;9(10):e109490.

24. Demirci $K$, Akgönül $M$, Akpinar A. Relationship of smartphone use severity with sleep quality, depression, and anxiety in university students. J behavioral addictions. 2015 Jun;4(2):85-92.

25. Hanika IM. Fenomena phubbing di era milenia (ketergantungan seseorang pada smartphone terhadap lingkungannya). Interaksi: Jurnal Ilmu Komunikasi. 2015;4(1):42-51.

26. Sukhonthachit P, Aekplakorn W, Hudthagosol C, Sirikulchayanonta C. The association between obesity and blood pressure in Thai public school children. BMC Public Health. 2014 Dec;14(1):729. 